УДК 811.161

DOI https://doi.org/10.26661/2522-4360-2021-2-06

\title{
МЕТОДИЧНІ ЗАСАДИ РОБОТИ З НАУКОВИМ ТЕКСТОМ У ЗВО: ТЕОРЕТИКО-ПРАКТИЧНИЙ АСПЕКТ
}

\author{
Рускуліс Л. В. \\ доктор педагогічних наук, \\ доцент кафедри лінгводидактики та стилістики, \\ завідувач кафедри української мови і літератури \\ Миколаївський національний університет імені В. О. Сухомлинського вул. Нікольська, 24, \\ Миколаїв, Україна \\ orcid.org/0000-0003-2293-5715 \\ ruskulis_lilys@ukr.net \\ Ковалик М. О. \\ кандидат філологічних наук, \\ дочент кафедри соиіально-гуманітарних дисцииллін \\ Первомайська філія \\ Національного університету кораблебудування імені адмірала Макарова \\ вул. Одеська, 107, Первомайськ, Миколаӥвська область, Украӥна \\ orcid.org/0000-0003-0165-9002 \\ marichkakuz@gmail.com
}

\begin{abstract}
Ключові слова: науковий текст, науковий стиль, підстилі наукового стилю, принципи укладання наукових текстів, науковий спосіб мислення, науковий предмет дослідження.
\end{abstract}

У статті наголошено, що домінантним завданням закладів вищої освіти $є$ формування науково зрілого студента, який здатен створювати і продукувати наукову продукцію; на основі аналізу наукових джерел з'ясовано поняття «науковий текст», який визначено як засіб передавання наукового способу мислення, наукових знань про той чи той науковий предмет дослідження, який впливає на науковий прогрес людства; звернено увагу на поділ текстів за будовою на: первинні (основна мета - передавання первинної інформації, здобутої під час наукових студіювань (монографія, дисертація, дипломні роботи бакалавра та магістра)); вторинні (основна мета - аналіз змісту первинних текстів (наукова стаття, тези, реферати, анотації, огляди, звіти тощо)); охарактеризовано принципи укладання наукових текстів: змістовної насиченості; наукової інформативності; новизни наукового тексту; змістової завершеності; проблемності; доступності фахівцеві тієї чи тієї галузі; інтертекстуальності; доведено, що принцип інтертекстуальності дає можливість виокремити різновиди текстів, які є складниками наукового, а саме оглядового, методологічного, емпірико-фактологічного, теоретичного, пояснювального й додаткового текстів; висвітлено вимоги до наукового тексту: чітка структура; обдумане використання графічного матеріалу; системність у процесі написання тексту; виправдане використання цифр і фактів тощо; розроблено та запропоновано систему завдань, які пропонують роботу над текстами, що $є$ взірцями різних підстилів наукового стилю (власне науковий, науково-методичний, науково-інформаційний, науководіловий, науково-фантастичний); передбачено, що студенти не тільки аналізуватимуть тексти на лексичному, граматичному та стилістичному рівнях, а й самостійно укладатимуть словник термінів майбутньої професії; працюватимуть над написанням наукових статей та тез, укладаючи список необхідної літератури та reference. 


\title{
METHODOLOGICAL PRINCIPLES OF WORKING WITH SCIENTIFIC TEXT IN HIGHER EDUCATION INSTITUTIONS: THEORETICAL AND PRACTICAL ASPECT
}

\author{
Ruskulis L. V. \\ Doctor of Pedagogical Sciences, \\ Associate Professor at the Department of Linguistic Didactics and Stylistics, \\ Head at the Department of Ukrainian Language and Literature \\ V. O Sukhomlinsky Mykolaiv National University \\ Nikolska str., 24, Mykolaiv, Ukraine \\ orcid.org/0000-0003-2293-5715 \\ ruskulis_lilys@ukr.net \\ Kovalyk M. O. \\ Candidate of Philology (Ph.D. in Philology), \\ Associate Professor at the Department of Social and Humanitarian Disciplines \\ Pervomaisk Branch of Admiral Makarov National University of Shipbuilding \\ Odeska str., 107, Pervomaisk, Mykolaiv region, Ukraine \\ orcid.org/0000-0003-0165-9002 \\ marichkakuz@gmail.com
}

Key words: scientific text, scientific language (style), backgrounds of scientific style; principles of compiling scientific texts; scientific way of thinking; scientific subject of study.

\begin{abstract}
The article emphasizes that the dominant task of higher education institutions is to form a scientifically mature student who is able to create and produce scientific products. Based on the analysis of scientific sources, the concept of "scientific text" has been clarified, which is defined as a means of transmitting the scientific way of thinking, scientific knowledge about a scientific subject of study, which affects the scientific progress of mankind. Attention is paid to the division of texts by structure into: primary texts (their main purpose is to transfer primary information obtained during scientific study (e.g. monograph, dissertation, bachelor's and master's theses)) and secondary texts (their main goal is to analyse the content of primary texts (e.g. scientific article, abstracts, reports, annotations, reviews, etc.)). The principles of compiling scientific texts have been characterised: content saturation; scientific informativeness; novelty of the scientific text; semantic completeness; problematicity; accessibility to an expert in a particular field and intertextuality. It is proved that the principle of intertextuality makes it possible to distinguish types of texts that are components of the scientific, namely: review, methodological, empirical and factual, theoretical, explanatory and additional texts. The requirements for the scientific text have been highlighted such as clear structure; deliberate use of graphic material; systematic in the process of writing the text and justified use of numbers and facts, etc. A system of tasks has been developed and proposed, which offers work on texts that are examples of different backgrounds of scientific style (actually scientific, scientific-methodical, scientificinformational, scientific-business and scientific-fantastic). It is envisaged that students will not only analyse texts at the lexical, grammatical and stylistic levels, but also independently compile a dictionary of terms of the future profession; will work on writing scientific articles and abstracts, compiling a list of necessary literature and references.
\end{abstract}

Постановка проблеми. Потреба максимально висвітлити наукову діяльність, розвиток суспільства в галузі науки, його прогресивні напрями спонукають науковців до розроблення єдиних вимог до наукового тексту, його кодифікації та вдосконалення, бо, як наголошує О. Баженова, наукові твори стають складником наукового пізнання й, відповідно, культурного контексту суспільства 
і поповнюють глобальний його зміст [1, с. 62]. Отже, одним із магістральних завдань сучасної вищої школи $є$ формування науково зрілого студента, який здатен створювати й продукувати наукову продукцію, бо від якості тексту «може залежати доля дослідження, його сприйняття науковим співтовариством, вплив цього дослідження на процес розвитку науки», адже відмінно написаний текст широко цитується, до нього звертається багато науковців, а невдалий не сприймається науковою спільнотою [6, с. 80].

Теоретичною основою дослідження $є$ накопичений досвід учених щодо з'ясування особливостей функціювання наукового стилю та його підстилів у системі стилістики сучасної української літературної мови (І. Білодід, Ф. Бацевич, П. Дудик, І. Кочан, Л. Мацько, М. Пентилюк, О. Семеног, Ю. Сурмін, О. Пономарів та ін.); дослідження теоретичних основ наукового тексту в лінгвістиці (Ф. Бацевич, І. Вихованець, К. Городенська, I. Кочан, М. Кочерган, Г. Онуфрієнко, Л. Паламар, М. Пентилюк, О. Семеног, Ю. Сурмін, О. Тараненко та ін.); студіювання шляхів упровадження навчально- та науково-дослідницької діяльності у ЗВО (Ю. Бєляєв, О. Земка, М. Князян, О. Копусь, Н. Краус, Н. Кушнаренко, В. Мельничайко, Ю. Набока, М. Пентилюк, Л. Рускуліс, О. Семеног, 3. Слєпкань, Ю. Сурмін, Г. Цехмістрова, В. Шейко та ін.).

Мета статті полягає у з'ясуванні теоретичних основ наукового тексту, розробленні системи вправ для роботи над науковим текстом.

Виклад основного матеріалу. Основною одиницею наукового стилю $є$ науковий текст, вивчення особливостей якого пов' язано «з цілою низкою чинників, серед яких можна назвати такі, як: процес глобалізації, що охоплює всі сторони суспільного життя, у тому числі і науку; активізація міжкультурної наукової комунікації як наслідок цього процесу; неослабний інтерес до проблем тексту взагалі і наукового тексту зокрема, зумовлений місцем тексту в процесі комунікації, і водночас недостатня вивченість феномену наукового тексту в міжкультурному, соціальному і комунікативно-когнітивному аспектах; визнання англійської мови глобальною мовою міжкультурної наукової комунікації; поява нової парадигми опису мови, а разом з нею і нових якісних методів дослідження» [2].

Науковий тест, як зазначає О. Семеног, - це «цілісний комунікативний блок, що має чітку, логічну структуру із внутрішньо завершеними частинами (розділами, підрозділами, пунктами, параграфами, абзацами), насиченими відповідною термінологією [9, с. 63]. Нам імпонує думка Г. Онуфрієнко про те, що науковий текст є вищою комунікативною одиницею «в межах наукового дискурсу як вербальне, цілісне, структуроване, когнітивно-комунікативне утворення, що характеризується структурно-семантичною, композиційно-стилістичною і функціональною єдністю та набором константних текстових категорій» [7, с. 336]. У розвідці також звертаємося до праць Ю. Сурміна, де наголошено, що «науковий текст виступає способом подання наукової інформації, результатом наукового дослідження. Він $є$ тим інтелектуальним продуктом, що доводиться до наукової громадськості» $[10$, с. 5]. Погоджуємося й із думкою науковців, що основною ознакою наукових текстів $є$ вироблення й домінування нових знань, «індексування семантики тексту для інформаційного пошукування, творення баз даних i знань, укладання перекладних, тлумачних, дефініційних та інших словників, перекладання текстів 3 однієї мови на іншу тощо» [8]. Отже, науковий тест - засіб передавання наукового способу мислення, наукових знань про той чи інший науковий предмет дослідження, який упливає на науковий прогрес людства.

За будовою наукові тексти поділяються на: a) первинні (основна мета - передавання первинної інформації, здобутої під час наукових студіювань (монографія, дисертація, дипломні роботи бакалавра та магістра)); б) вторинні (основна мета - аналіз змісту первинних текстів (наукова стаття, тези, реферати, анотації, огляди, звіти тощо)) [9, с. 20-21]. Вважаємо за необхідне також звернути увагу на класифікацію Ю. Сурміна щодо поділу наукових текстів на тексти-констатації, що висвітлюють результат дослідження, фіксування його, утвердження дійсності, та тексти-міркування, в яких наявна не тільки констатація фактів, а й висловлені сумніви до окремих положень, пропонуються власні думки чи припущення $[10$, c. $5-7]$.

У науковій літературі знаходимо визначення принципів укладання наукових текстів: змістовної насиченості - інноваційність запропонованої інформації, пізнавальна цінність іiі; професійне ядро-необхідність проаналізованоїінформаціїдля конкретної сфери діяльності; наукової інформативності - авторська концепція репрезентованого дослідження; новизни наукового тексту - наявність нових положень, які можна буде впровадити в практику; змістової завершеності - цілісність розкритих положень; проблемності - кодування проблемних питань; доступність фахівцеві тієї чи тієї галузі - легкість сприйняття інформації та розуміння 'iï; інтертекстуальність - зв'язок наукового тексту з іншими видами текстів [9, с. 63-64]; декларативність тексту - чіткий порівняльний аналіз певного процесу або явища $[6$, с. 80]. Принцип інтертекстуальності дає можливість виокремити різновиди текстів, що є складниками наукового, 
a саме: оглядового тексту (ступінь репрезентації питання в наукових колах), методологічного (узагальнення підходів, закономірностей, принципів, методів дослідження з метою опису особливостей авторської методології проведення пошуку), емпірико-фактологічного (опис, класифікація, групування, узагальнення фактів), теоретичного (тлумачення предмета дослідження), пояснювального (примітки, пояснення, покликання на інші джерела) й додаткового (схеми, малюнки, графічні зображення) [4; 9].

До наукового тексту виставлено певні вимоги, a саме: чітка структура (поділ на розділи (які є самостійним складником загальної теми дослідження), параграфи, абзаци й речення (утворення цілісної думки та без надмірного їх дроблення), що тісно пов'язані між собою), виключення повторів (зокрема у висновках до розділів та в загальних висновках); обдумане використання графічного матеріалу [3, с. 7]; системність у процесі написання тексту, що полягає в умінні відшуковувати системоутворювальні фактори; уникнення понять, які не можна однозначно інтерпретувати, бо це призводить до зменшення конкретизації їх; виправдане використання цифр і фактів, оскільки необдумано велика кількість їх - великий недолік роботи; цілісність тексту [6, с. 87].

Отже, науковий текст репрезентує особливості наукового стилю сучасної української літературної мови. Його характеризують певні структурні, змістові, мовні особливості, які слід засвоїти студентові закладу вищої освіти, щоб вести активні наукові пошуки.

Визначені теоретичні засади дослідження наукового стилю сучасної української літературної мови та особливості навчально- й науково-дослідницької роботи студентів закладів вищої освіти визначають систему вправ для вивчення підстилів наукового стилю та вдосконалення науково-дослідницької роботи. Наведемо приклади завдань.

Завдання 1. Прочитайте текст. До якого підстилю наукового стилю його слід віднести? Думку обгрунтуйте.

Зразок 1. Дистаниійна освіта (ДО) - сукупність інформаційних технологій, щзо забезпечують доставку студентові основного обсягу матеріалу; інтерактивну взаємодію студентів та викладачів в просі навчання; надання студентам можливості самостійної роботи із засвоєного матеріалу, а також оцінку їх знань та навичок у процесі навчання [1, с. 200]; комплекс освітніх послуг, щзо надаються за допомогою спеиілалізованого інформаичійно-освітнього середовиша на будь-якій відстані від освітніх установ [6, с. 131]; універсальна форма навчання, щзо базується на використанні можливостей широкого спектра традиційних, нових інформаційних, теле- комунікаційних технологій та технічних засобів, які створюють для користувача умови вільного вибору дисциплін, діалогового обміну з викладачем без урахування відстані та часу [5, с. 211].

Зразок 2. До професійних компетентностей I. Зимня відносить: а) пізнавальну діяльність (створення, дослідження й нестандартні розв'язання проблемних завдань, ситуацій); б) діяльність (планування, проектування й розігрування гри, дослідницька діяльність); в) інформащзійні технологї (отримання й опрацювання інформації, презентація ї̈; навички користування електронною поштою, упровадження мультимедійних проектів, розвиток комп'ютерної досконалості) [77, с. 40]. Вбачаємо за необхідне звернутися до класифікації О. Малихіна, щуо охоплює такі види професійної компетентності: психолого-педагогічну; фахово-предметну; методологічну; методичну; самоосвітню [109, с. 69].

Післятекстові завдання:

1. Фахівцям якої галузі адресований текст? Проаналізуйте лексеми на підтвердження ваших міркувань.

2. Які мовні кліше репрезентують особливості наукового стилю в наведеному уривку?

3. Зверніть увагу на особливості синтаксичних конструкцій, вжитих у тексті. Зробіть висновки.

4. Зверніть увагу на правила оформлення покликань у тексті та вимоги до укладання списку використаних джерел. Укладіть список джерел до теми, яка розкривається в уривку. Оформіть references. Чому в процесі написання наукових статей reference $\epsilon$ обов' язковим елементом?

Запропоновані завдання базуються на опрацюванні текстів, узятих із дисертацій на здобуття кандидата (перший уривок) та доктора (другий уривок) педагогічних наук. Їхня основна мета повідомити наукову інформацію, проаналізувати iii. Уривки насичені мовними кліше, термінами, книжними словами. Виклад матеріалу чіткий, логічний та лаконічний, оскільки невеликі тексти охоплюють аналіз значного мовного матеріалу. Робота над текстами супроводжується аналізом на наявність термінологічної лексики, укладанням списку посилань.

Завдання 2. Ознайомтеся із запропонованим текстом. Яке, на вашу думку, його призначення та до якого підстилю наукового стилю цей текст слід уналежити? 3'ясуйте основне призначення підстилю та його особливості на лексикологічному рівні.

Iз часу виникнення науки про мову можна говорити й про складову частину мовознавства культуру мовлення. Адже, створюючи словники, граматики, тлумачення текстів, завжди доводиться добирати, очінювати, класифікувати мовні факти. А узагальнені в лінгвістичних праиях, вони сприяли усталенню, поширенню тих чи 
інших норм, їх кодифікації. Культура мовлення як галузь мовознавства оформилася в системі лінгвістичних дисииплін як власне практичний курс у 50-60 роки ХХ століття.

Над питанням культури мовлення працювали украйнські вчені, методисти Н. Бабич, О. Біляєв, Д. Ганич, М. Жовтобрюх, С. Срмоленко, А. Коваль, М. Пентилюк, М. Пилинський, I. Синиия, $\epsilon$. Чак та інші; серед російських науковців можна назвати Б. Головіна, В. Костомарова, С. Обронського, Л. Сквориова, В. Чернишова, Л. Щербу та ін.

Післятекстові завдання:

1. 3'ясуйте різницю між поняттями «культура мови» та «культура мовлення», відредагувавши запропонований текст.

2. Випишіть термінологічну лексику, що використана в уривку, дайте визначення цим термінам. Укладіть власний термінологічний словник термінів вашої майбутньої професії.

3. Схарактеризуйте особливості мовленнєвого етикету українців. Які специфічні мовленнєві форми звертання, привітання чи прощання характерні носію української мови?

4. Укладіть тези, в яких розкрийте запропоновану проблему. Виступіть із повідомленням перед студентською аудиторією.

5. Підготуйте анотацію на статтю (автор за вибором), в якій розкрито проблеми формування мовленнєвої культури сучасної молоді.

Запропоноване завдання передбачало опрацювання науково-навчального та науково-інформативного підстилів наукового стилю. Текст завдання - яскравий взірець науково-навчального підстилю, оскільки репрезентує фрагмент методичного посібника. Інформацію подано чітко, аргументовано, доступно як для викладачів закладів вищої освіти, так і для студентів. Запропоновані післятекстові завдання охоплюють роботу над опрацюванням особливостей термінологічної лексики, розрізнення подібних понять, звернення до історичних коренів української мови щодо з'ясування особливостей українського мовленнєвого етикету.

Завдання 3. Проаналізуйте словникові статті. 3'ясуйте, яке магістральне призначення науково-довідкового підстилю наукового стилю.

Земля, ж. 1. Суша (на відміну від водного простору). Верхній шар кори нашої планети. Обробіток землі.3. Розсипчаста темна бура речовина, що входить до складу нашої планети. Пімана земля. 4. Територія з угіддями, щзо перебуває в чиєму-небудь володінні, користуванні. Краӥна, держава. 6. (з великої літери) Третя від Сония планета сонячної системи, на якій ми живемо. 7. Місяиь - супутник Землі. 7. перен. Місие життя i діяльності людей (Зі словника).
Післятекстові завдання:

1. Яке місце займають словники в професійній діяльності? Проаналізуйте особливості побудови словників.

2. Дайте відповіді на такі запитання: які функції виконують словникові статті; які види словникових статей визначають науковці; від яких умов залежить розмір наукової статті; що таке реєстр словникових статей; дайте визначення поняття «реєстрове слово»; які виокремлено джерела поповнення словникових статей?

3. Які рівні мовної норми зафіксовано в лінгвістичних словниках? Які у словниках використовуються позначки для демонстрації акцентологічних, орфоепічних, лексичних, фразеологічних, граматичних норм?

4. Укладіть невеликий словник термінів майбутнього фаху, вибудувавши словникову статтю, яка б відповідала усім вимогам оформлення такого виду робіт.

5. Схарактеризуйте основні напрями словникової роботи, написавши наукові тези (до трьох сторінок). Укладіть список використаної літератури, підготуйте reference.

Запропоноване завдання об'єднує опрацювання науково-інформаційного та науково-ділового підстилів наукового стилю сучасної української літературної мови. Студенти, ознайомившись зі словниковими статтями, зможуть не тільки охарактеризувати домінантні особливості науково-інформаційного підстилю (чіткість, лаконічність, терміносистемність тощо), а й самостійно вибудувати словникову статтю відповідно до вимог, які з'ясовано в післятекстових завданнях. Виконання такого виду завдань не лише уможливлює кропітку наукову діяльність студентів, а й сприяє розширенню їхнього тезаурусу, уточненню значень слів, які вони використовують у повсякденному мовленні, збагачує їхній активний словник, допомагає витіснити нелітературну лексику.

Завдання 4. Ознайомтеся зі змістом тексту. Розставте розділові знаки і звірте їх з авторськими.

У Буенос-Айресі Зуріта дізнався, що доктор знаменитий своїми сміливими операчіями. «Під час імперіалістичної війни він був на франиузькому фронті, де займався майже виключно операиіями черепа». Після війни Сальватор повернувся в Аргентину $i$ зайнявся наукою.

Одного разу до Сальватора прийшов старий індіанещь Крісто (Христофор) з хворою онукою. Доктор вилікував дівчинку. Із вдячності Крісто захотів присвятити доктору залишок свого життя. Сальватор «неохоче $і$ обережно брав нових слуг», але роботи було багато, і Крісто потрапив у будинок доктора. Спочатку індіанець прачював у зовнішньому саду, обгородженому двома високими стінами. Там жило безліч дивних 
тварин: двоголові змї $і$ щурри, горобиі з головою папуги, лами з кінськими хвостами і мавпи, щзо могли розмовляти. Обслуговували цуей сад дуже мовчазні негри (За О. Бєляєвим).

Післятекстові завдання:

1. До якого підстилю наукового стилю слід уналежити текст? Які його особливості? Думку обгрунтуйте. Які міжстильові вкраплення в ньому ви можете визначити.

2. Доведіть приналежність тексту до науково-фантастичного підстилю, проаналізувавши його на лексичному рівні. Проаналізуйте граматичний рівень тексту.

3. Перебудуйте текст так, щоб він репрезентував: а) власне науковий підстиль; б) науково-інформаційний; в) науково-діловий; г) науково-навчальний.

4. Виконайте зіставний аналіз власне наукового (академічного) підстилю та науково-фантастичного. Вкажіть спільні й відмінні ознаки.

Запропонований текст є взірцем науково-фантастичного підстилю наукового стилю. Виконання завдань базувалося на специфічних принципах навчання стилістики - стилістичному редагуванні та стилістичному конструюванні.

Висновки і перспективи подалыших розробок. Отже, розроблена та запропонована система вправ із формування навичок роботи з науковим текстом, на нашу думку, повністю відповідає тим вимогами, які ми визначили в процесі їх розроблення. Завдання, вибудовані на текстоцентричній основі, безумовно, формують лексикологічну, граматичну, правописну, стилістичну компетентності, оскільки студенти повинні вміти витлумачити значення слова, здійснити його лексикографічну характеристику, 3'ясувати місце в системі сучасної української літературної мови, проаналізувати морфологічну й синтаксичну структуру текстів, розставити розділові знаки. Ми переконані, що розроблені вправи ефективно формуватимуть наукову компетентність студента закладу вищої освіти. У подальшому планується розкриття проблем академічної культури студента в процесі навчання в закладі вищої освіти під час продукування текстів наукового стилю.

\section{ЛIТЕРАТУРА}

1. Баженова Е. Научный текст и среда. Вестник Пермского университета. Российская и зарубежная филология. 2010. Вып. 2. С. 60-64.

2. Іщенко Н. , Ліпінська В. Лексико-граматичні домінанти наукового тексту. Вісник НТУУ «КПІ». Філологія. Педагогіка: зб. наук. пр. 2014. С. 32-41.

3. Клименюк О. Виклад та оформлення результатів наукового дослідження: підр. Ніжин: Аспек-Поліграф, 2007. 398 с.

4. Корюкова, А.А., Дера В.Г. Основы научно-технической информации: учеб. пособ. М.: Высш. шк., 1985. $224 \mathrm{c}$.

5. Краус Н.М. Методологія та організація наукових досліджень: навч.-метод. посіб. Полтава: Оріяна, 2012. $183 \mathrm{c}$.

6. Методологія наукових досліджень. Тексти лекцій для студентів галузі знань 05 - Соціальні та поведінкові науки, спеціальності 051 - Економіка, освітньої програми «Економіка довкілля та природних ресурсів» денної форми навчання / Укладачі: Дерій Ж. В., Зосименко Т. І. Чернігів: ЧНТУ, 2018. $113 \mathrm{c}$.

7. Онуфрієнко Г.С. Науковий текст у сучасному лінгводидактичному вимірі. Вісник Запорізького національного університету. Філологічні науки. № 1, 2012. С. 334-339.

8. Пшенична Л., Шевченко В., Шишкіна Н Термінологічна робота: науковий текст як джерело нових знань. URL: http://vlp.com.ua/files/02_38.pdf.

9. Семеног О.М. Культура наукової української мови: навч. посіб. К.: ВЦ «Академія», 2010. 216 с. (Серія «Альма-матер»).

10. Сурмін Ю.П. Наукові тексти: специфіка, підготовка та презентація: навч.-метод. посіб. К.: НАДУ, 2008. $184 \mathrm{c}$.

\section{REFERENCES}

1. Bazhenova, E. (2010). Nauchnyi tekst i sreda [Scientific text and environment]. Vestnik Permskogo universiteta. Rossiiskaia i zarubezhnaia filologiia, 2, 60-64 [in Russian].

2. Ishchenko, N., \& Lipinska, V. (2014). Leksyko-hramatychni dominanty naukovoho tekstu [Lexico-grammatical dominance of the scientific text]. Visnyk NTUU "KPI". Filolohiia. Pedahohika, 32-41 [in Ukrainian].

3. Klymeniuk, O. (2007). Vyklad ta oformlennia rezultativ naukovoho doslidzhennia [Presentation and registration of research results]. Nizhyn: Aspek-Polihraf [in Ukrainian].

4. Koriukova, A.A., \& Dera, V.G. (1985). Osnovy nauchno-tekhnicheskoi informatcii. [Fundamentals of scientific and technical information]. Moskva: Vyssh. shk. [in Russian]. 
5. Kraus, N.M. (2012). Metodolohiia ta orhanizatsiia naukovykh doslidzhen [Methodology and organization of scientific research]. Poltava: Oriiana [in Ukrainian].

6. Derii, Zh.V., \& Zosymenko, T.I. (Ed.). (2018). Metodolohiia naukovykh doslidzhen. Teksty lektsii dlia studentiv haluzi znan 05 - Sotsialni ta povedinkovi nauky, spetsialnosti 051-Ekonomika, osvitnoi prohramy «Ekonomika dovkillia ta pryrodnykh resursiv» dennoi formy navchannia [Research methodology. Texts of lectures for students of the field of study "05 Social and behavioural sciences", Programme Subject Area "051 Economics", Educational Program "Economics of Environment and Natural Resources" full-time mode of study]. Chernihiv: ChNTU [in Ukrainian].

7. Onufriienko, H.S. (2012). Naukovyi tekst u suchasnomu linhvodydaktychnomu vymiri [Scientific text in the modern linguodidactical dimension]. Visnyk Zaporizkoho natsionalnoho universytetu. Filolohichni nauky, 1, 334-339 [in Ukrainian].

8. Pshenychna, L., Shevchenko, V., \& Shyshkina, N. (2008). Terminolohichna robota: naukovyi tekst yak dzherelo novykh znan [Terminological work: a scientific text as a source of new knowledge]. Retrieved from http://vlp.com.ua/files/02_38.pdf [in Ukrainian].

9. Semenoh, O.M. (2010). Kultura naukovoi ukrainskoi movy [Culture of the scientific Ukrainian language]. Kyiv: VTs «Akademiia» (Seriia «Alma-mater») [in Ukrainian].

10. Surmin, Yu.P. (2008). Naukovi teksty: spetsyfika, pidhotovka ta prezentatsiia [Scientific texts: specifics, preparation and presentation]. Kyiv: NADU [in Ukrainian]. 